\title{
LA ESTAMPA COMO FUENTE DEL ARTE EN LA NUEVA ESPAÑA
}

Jorge Alberto Manrique

A partir de la conquista, América y México - la Nueva España - que en este caso será el punto de mi atención, ingresan al mundo de la cultura occidental. Señalar este hecho implica necesariamente asumir los matices de tal traslación de cultura, de esa "portátil Europa", según la feliz metáfora de Baltazar Gracián. Matices cuyo trabajoso deslinde corresponde al historiador, al antropólogo, al etnólogo, al sociólogo, y a otros, entre los cuales está el historiador del arte. Esos deslindes diferenciales son los que dan a América y a la Nueva España, en los años de la época colonial -y después - una situación particular y peculiar en dos sentidos: el ser partícipes y co-formadoras de la cultura occidental a partir del siglo XVI, y el constituir un modo particular de esa misma cultura occidental.

En este caso me ocuparé someramente de los problemas que implica el grabado generado en Europa, como fuente del arte novohispano: de qué manera los grabados determinan el arte de la Nueva España, pero lo determinan contradictoriamente como similar y simultáneamente diferente.

Haré la presentación de los problemas en referencia a dos momentos históricos y artísticamente muy diferenciados en la Nueva España, es a saber, las décadas inmediatas posteriores a la conquista, y después los periodos manierista y barroco. ${ }^{1}$

\section{Décadas inmediatas posteriores a la conquista}

En las décadas inmediatas a la conquista la situación es la de un mundo novohispano cuya misión teórica fundamental es la de la evangelización de una muchedumbre innumerable de neófitos. La Iglesia católica precisa en su culto - lo confirmaría después en Trento- de imágenes. ${ }^{2} \mathrm{Y}$ la Nueva España es, en esas décadas, una hambrienta insatisfecha de imágenes: necesarias para enseñar, necesarias para convertir, necesarias para la perseverancia y la reafirmación de la nueva fe. Necesarias también para la práctica religiosa de los europeos

Antes de mediados del siglo XVI el grabado europeo no había tenido aún el auge y proliferación que conocería después. Los franciscanos, dominicos y

1 La bibliografía de autores que han identificado las fuentes particulares de obras mexicanas en grabados europeos es amplísima, en libro y sobre todo artículos, imposibles de citarse aquí. Han hecho aportaciones notables Manuel Toussaint, Diego Angulo, George Kubler, Erwin Walter Palm, Santiago Sebastián, entre muchos otros.

${ }^{2}$ El Concilio de Trento, en su sesión 25 , como es sabido, confirma la conveniencia y necesidad de las imágenes e historias de la religión 
agustinos sobre cuyos hombros recayó la tarea evangelizadora, no estaban en posibilidad de traer "bultos" (esculturas), ni pinturas, ni aun grabados que reprodujeran la obra de los grandes maestros. Traían, sólo, libros de catecismo y de teología. Y esos libros fueron la fuente casi única de la primera iconografía novohispana.

No sólo la fuente era restringida. En esas primeras décadas el paso de artistas a la Nueva España fue más bien raquítico: ni muchos artistas ni artistas con una formación amplia o con capacidades mayores en su arte. Frente a la gran necesidad de imágenes, unas fuentes muy reducidas y una mano de obra muy limitada. Había que acudir a los neófitos. Casi toda la arquitectura, la escultura y la pintura del siglo XVI es obra de indios conversos dirigidos por unos pocos y poco hábiles artífices europeos. No, como a menudo se ha dicho, por la utilización de los antiguos tlacuilos: los frailes comprendieron muy bien la estrechísima relación en el mundo azteca entre arte y religión, y así como no tomaron a los antiguos tlamatinime para enseñarles teología, tampoco acudieron a los artistas de la religión antigua, sino a muchachos hijos de caciques, a quienes enseñaron ${ }^{3}$ Podemos entender qué podría ser la escuela de fray Pedro de Gante en San José de los Naturales: ni fray Pedro era artista, ni tenía a su alrededor artistas muy capaces; la escuela debe haber sido, sobre todo, una en que se enseñaba a leer la iconografía, a entender los modelos posibles, y a no incurrir en errores dogmáticos. Todavía para 1552, don Luis de Velasco, segundo virrey, da un auto en que obliga a todo pintor a examinar sus obras en la capilla de San José de los Naturales: su intención sería más la de preservar el dogma y prevenir la irreverencia, que cuidar las cualidades estrictamente artísticas. ${ }^{4}$

Muy pronto, después de la aparición de la imprenta en Europa, los impresos solian ir acompañados de grabados, algunos ilustrando el texto, después otros - de carácter arquitectónico fantástico- en la "portada"; otros como cenefas decorativas, viñetas o letras capitulares. Todos ellos, ante la necesidad de modelos, eran utilizables en la Nueva España. En esa circunstancia, vale plantear tres aspectos centrales:

a) Dado que los libros-fuente no correspondían a un mismo momento, sino que eran desde incunables del siglo XV hasta las últimas ediciones de media-

\footnotetext{
* Un caso típico y bien documentado es el del cacique pintor Juan Gerson, quien realizara las pinturas del sotocoro de Tecamachalco

Rosa Camelo, Jorge Gurria Lacroix y Constantino Reyes, Juan Gerson, Tlacuilo de Tecamachalco, México, INAH, 1964

4 " ... algunos indios pintores ... pintan imágenes así en sus casas como en otras partes, los cuales como no están examinados hacen dichas imágenes sin aquella perfección que se requiere, en oprobio y deservicio de Dios Nuestro Señor... or denado y mando que ningún indio ... no sean osados de pintar... hasta que sean examinados y en el entretanto se examinen sus imágenes en la dicha capilla de San José para que ahí se vea si van con aquella perfección que conviene y se requiere.." Transcripción completa del auto en Manuel Toussaint: Pintura colonial en México (edic. preparada por X, Moyssén) México, UNAM. Instituto de Investigaciones Estéticas, 1965; p. 218.
} 
dos del siglo XVI, los modelos ofrecen una especie de "confusión temporal" Formas tipográficas gotizantes o renacentistas convivían en las bibliotecas frailunas, y jugaron parejas como modelos. Este rasgo de "atemporalidad" será persistente en la Nueva España.

b) Los modelos de decoración tipográfica o modesta ilustración de libros eran casi los únicos a mano: con el resultado de que se utilizaron por igual como luentes para la pintura, la escultura y la arquitectura. Una portada fantasiosa de un libro puede tener su contraparte pétrea en una monumental portada de iglesia.

c) La tipografía (grabados en madera exclusivamente), implicaba un tipo definido de representación de la forma: lineal, con lineas preferentemente rectas, con simulación del volumen por medio de achurado, etc. Ese tipo de representación provenía de una determinada tradición del dibujo europeo, y de una necesaria adaptación de esa tradición dibujística a la madera a que era transportado. Para el lector europeo, inmerso en ese ambiente, que había mamado tal proceso de transformación de la realidad en formas canónicas, aquello resultaba fácilmente comprensible. No era lo mismo para el neófito natural, ajeno a aquella tradición, y que era incapaz de hacer una correcta lectura del grabado. Cuando se le pedía trasladar al fresco o al relieve aquellos modelos, los copiaba literalmente, por una incapacidad cultural de comprenderlos en modo cabal. Se ha hablado mucho de una "influencia indigena" en el arte del siglo XVI, que acostumbramos llamar "tequitqui": la realidad, a mi modo de ver, es que esas diferencias que encontramos entre el arte del siglo XVI y su coetáneo europeo, que individualizan tan claramente las obras novohispanas, no proceden de la dudosa y no verdaderamente documentable persistencia de lo azteca, sino más bien de una mala lectura de los modelos Lo que, desde luego, no disminuye su excelencia artística ${ }^{5}$

De tal manera, en las décadas que siguen a la conquista la fuente casi única para la iconografía y la ornamentación es el grabado: pero no la lámina que reproduce pinturas de maestros célebres, ni aun generalmente el grabado de un maestro reputado, sino las maderas que acompañan a los libros piadosos y teológicos. La presencia en México de la primera imprenta americana en 1536 y la fundación de la Universidad en 1551 no alteraron en un primer momento esa situación.

\section{Mamerismo y barroco}

I partir de una fecha hacia 1570 la situación artística en la Nueva España empieza a experimentar un cambio que resultará radical Muchas alteraciones en el orden económico, de población, social, administrativo, cultural y es-

"Ll asunto de la "inlluencia indigena" y la mano de obra de los indios sigue a discusión Pueden rerse como trabajos recientes sobre el tema: Constantino Reyes Valerio, Arte indoamericano, Mexico, Instituto Nacional de Antropologia e Historia, 1978 y Martha Fernández "Historia del cone epto de ate 'lequitqui"' (Tesis UNAM, 1976) 
tructural se conjugan en esas décadas finales del siglo XVI, tanto como para que quede rezagado y abandonado el "primer proyecto de vida novohispana" - de corte frailuno- y se forje un "segundo proyecto", que habria de prevalecer hasta el fin de la colonia. Por lo que toca a las artes, las diferencias más notables respecto al momento anterior son la presencia de numerosos pintores, escultores y arquitectos, con una formación esmerada en talleres europeos - principalmente pintores y escultores - y la formación de un gusto más refinado entre los habitantes de México y otras ciudades. Quienes determinarán el carácter de las obras no serán ya los frailes urgidos de la tarea evangelizadora y necesitados de imágenes, sino entendidos señores civiles o eclesiásti$\cos ^{6}$

Los artistas que ahora cruzan el océano están al tanto de las modas y usos especialmente en la pintura. Sus primeras obras ejecutadas al otro lado del Atlántico no difieren, ni en estilo ni en calidad, de lo que se produce normalmente en los talleres europeos. Traen, desde luego, en sus arcones buenas cantidades de grabados: ahora ya de grabados en metal, que recogen la obra de los maestros más alamados.

Estos artistas manieristas (Simón Perines, Andrés de Concha, Juan de Arrúe, Baltazar de Echave Orio, etc.) fundan en las décadas postreras del siglo XVI y los principios del XVII una tradición de arte culto, ajeno a los apremios misionales anteriores. Al utilizar grabados para concebir sus obras siguen desde luego una práctica generalizada en los talleres europeos.

Pero a partir del momento de su llegada a la Nueva España se inicia un proceso particular. Quedan aislados del medio en que se formaron, sin relación con ambientes artísticos más amplios, y con pocos recursos para estar al corriente de los cambios que se iban operando en Europa. Si agregamos que, una vez establecida una buena cantidad de talleres en las principales ciudades mexicanas, capaces de satisfacer las necesidades y el gusto locales, la inmigración de pintores y la importación de pinturas decreció muy notablemente - a partir del primer tercio del siglo XVII-, podemos hacernos una idea de su grado de aislamiento respecto a Europa ${ }^{7}$

Entregados a sus propias fuerzas, su estilo evoluciona y se desarrolla en esa situación excéntrica. Su contacto mayor con el proceso artístico europeo es la estampa grabada que, fácilmente transportable y relativamente barata, cruzaba continuamente el Atlántico para alcanzar las hambrientas manos de los pintores.

\footnotetext{
- Sobre los cambios en la vida novohispana y la presencia del manierismo, J A Manrique, "La época crítica de la Nueva España a través de sus historiadores" en Actas de la tercera reumón de hislonadures mézanos y norleamencanos, México, UNAM. El Colegio de México, 1971 y "Reflexiones sobre el manierismo en México" Anales del Instituto de Investiganones Estétuas núm 40, (1971)

7 Sobre el desarrollo de la pintura mexicana en esa época, Manuel Toussaint, Pintura colonial en México cit en n. 4; Guillermo Tovar y de Teresa, El Renacimiento en Méxıco, Méx. Instituto Nacional de Antropología e Histor ia, 1979; Rogelio Ruiz Gomar, "Un panorama y dos ejemplos de la pintura mexicana en el paso del siglo XVI al XVII" (tesis UNAM 1976).
} 
Retengamos sobre esto algunos aspectos fundamentales: i) El grabado, en esta segunda etapa es generalmente un grabado en metal, sobre la obra de los maestros afamados, o bien una estampa autónoma de calidad Es la casi única fuente formal e iconográfica de los pintores mexicanos ya nacidos en la Nueva España y creados en los talleres locales, su único medio de "estar al día" de los estilos y procesos del arte.

ii) Pero el grabado es, por definición, una fuente incompleta: proporciona composiciones, modelos de escorzo, pero es incapaz de dar cuenta del estilo verdadero de un pintor Porque éste queda "traducido" según las facultades del grabador y los recursos propios de la técnica de impresión; porque el color está ausente y el tratamiento de la luz es prácticamente intrasferible a la lámina

iii) Las novedades estilísticas aportadas por el grabado se inscriben y aceptan en el marco de las caracteristicas que la escuela mexicana adquiría en su situación excéntrica, y se someten a un proceso de modificación ineluctable, por las características de la escuela, el estilo particular de cada pintor, las necesidades locales en gusto y en usos iconográficos

iv) Siendo el flujo de grabados continuo en los siglos XVII y XVIII, sin embargo nunca llegan éstos a manos de los artistas en la cantidad que sus necesidades requieren. Si la limitación de modelos no alcanza la extrema carencia de las décadas inmediatas a la Conquista, no deja sin embargo de ser una constante en la Nueva España. En consecuencia, los artistas tienen que echar mano de sus viejas colecciones de grabados, y de las heredadas de sus maestros: el resultado es una suerte de mescolanza estilistica de las fuentes (sólo unificadas en manos de cada artista) y una especie de "atemporalidad" en la pintura novohispana Pueden confluir en un mismo taller grabados-fuentes de, por ejemplo, los finales del siglo XVI con otros de finales del XVII.

La situación excéntrica propia de la Nueva España, y su crónica carencia de modelos hace que el grabado importado de Europa siga siendo no sólo fuente para la pintura, sino también para otras artes, especialmente para la escultura, sobre todo para el relieve

El barroco mexicano usó profusamente, en el siglo XVII y en el XVIII, relieves en la parte central de las fachadas religiosas; los relieves son también muy comunes en otro tipo de obras decorativas, como retablos y sillerias y para el escultor es el grabado la fuente for mal casi exclusiva. Pero en este caso la "adecuación" del modelo y su traslado a materiales y circunstancias tan diferentes crea una distancia aún más notable

De tal manera, el grabado, en su capacidad extraordinaria para viajar a poco costo, constituye la fuente fundamental del arte de la Nueva España, tanto desde el punto de vista formal como desde el punto de vista iconográfico La Europa, "portátil" más que en ningún otro modo gracias a la existencia y desarrollo del arte de imprimir estampas, se hizo por este medio constantemente presente en el mundo y la conciencia del artista y del hombre de la Nueva España. Pero su imagen, enviada en hojas de papel impresas, y así 
reflejada del otro lado del Atlántico, le fue devuelta irreconocible Si el grabado, por su posibilidad de estar presente en todas partes, conformó el arte mexicano desde el siglo XVI hasta el XVIII, las limitaciones inherentes a su propia técnica y a su comercio siempre insuficiente, hicieron que ese arte se "deformara" respecto al modelo ideal de Europa: México pudo desarrollar un arte con características propias debido en buena parte a esa circunstancia La estampa mantuvo a Nueva España como una parte de Europa, pero como una parte cuya condición de excéntrica la hacía definitivamente diferente. 